ПИТАННЯ ВИХОВАННЯ УНІВЕРСАЛЬНОСТІ В СУЧАСНОМУ МУЗИЧНОМУ ВИКОНАВСТВІ

\title{
ISSUES OF EDUCATION OF UNIVERSALITY IN MODERN MUSIC PERFORMANCE
}

\begin{abstract}
Статтю присвячено дослідженню питання універсальності як характеристики, що необхідна в сучасній музичній виконавській діяльності. Універсальність творчої особистості виявляється як системна діяльність, в якій суміщається спів, гра на музичних інструментах, аранжування, композиція, а в деяких випадках - запис аудіо та відео та їх подальше редагування. Подібна настанова стає все більш затребуваною з огляду на ті риси, які характерні для сучасної практики реалізації музичної діяльності.
\end{abstract}

Існує відмінність між універсальністю виконавця та артистизмом. Виконавець у процесі гри чи співу має поєднувати їх із акторською грою, вмінням комунікувати 3 аудиторією, але ця синтетичність виконавської справи не може бути ототожнена з універсальністю. Універсальність сучасного музиканта можна продемонструвати на прикладі творчості Джейкоба Кольєра. Поєднання якостей інструменталіста, співака, аранжувальника та творця (композитора та режисера) музичного цілого роблять його зразковим виконавцем. Співак оволодів різними стилями та вокальними манерами, його манера презентації музичних творів характеризується значною експресією, динамічністю зміни музичних інструментів та прийомів гри на них, відкритістю. Значна неординарність виконавця привертає симпатію публіки, яка бурхливо реагує на концертних виступах, перебуваючи в неменшому захваті, ніж Кольєр.

Для формування виконавців подібного рівня універсальності виділяється низка дій: забезпечення закладів освіти мистецького спрямування технічним обладнанням, інструментарієм та кваліфрікованими педагогічними кадрами. Також важливим компонентом $\epsilon$ високий рівень вивчення музично-теоретичних дисциплін, а не лише виконавської практики. Розвинений слух, гармонічне чуття допомагають удоскона лювати рівень професіоналізму виконавця та виходити на більш високий рівень майстерності.
Ключові слова: виконавець, універсальність, аранжувальник, співак, композитор, виховання

The article is devoted to the study of the question of universality as a characteristic that is necessary in modern musical performance. The universality of the creative personality is manifested as a systemic activity that combines singing, playing musical instruments, arranging, composing and in some cases recording audio and video and their subsequent editing. Such guidance is becoming increasingly popular given the features that are characteristic of modern practice of musical activity. There is a difference between the versatility of the performer and artistry.

The performer in the process of playing or singing must combine them with acting, the ability to communicate with the audience, but this synthetic performance cannot be equated with universality. The versatility of the modern musician can be demonstrated by the work of Jacob Collier. The combination of the qualities of an instrumentalist, singer, arranger and creator (composer and director) of a music whole makes him an exemplary performer. The singer has mastered different styles and vocal manners; his manner of presentation of musical works is characterized by significant expression, dynamic change of musical instruments and techniques of playing them, openness. The significant unusualness of the performer attracts the sympathy of the audience, which reacts very violently to concert performances, being no less delighted than Collier.

In order to form performers of this level of universality, a number of actions are distinguished. This is the provision of art education institutions with technical equipment, tools and qualified teaching staff. Also an important component is the high level of study of music-theoretical disciplines, not only performance practice. Developed hearing, harmonious sense help to improve the level of professionalism of the performer and reach a higher level of skill. Key words: performer, universality, arranger, singer, composer, education.

ПВНЗ «Київський університет культури»

Постановка проблеми в загальному вигляді. Сучасне музичне виконавство нині знаходиться на досить високому рівні розвитку. Актуальні тенденції спрямованості музичного простору зумовлюють потребу фрормування такої якості, як універсальність. Це здатність бути високопрофесійним виконавцем - вокалістом, інструменталістом, яка суміщається 3 іншими формами музичної діяльності - аранжуванням, композицією. Подібна настанова стає все більш затребуваною з огляду на ті риси, які характерні для сучасної практики реалізації музичної діяльності. Тому потрібно роз- крити, яким чином універсальність виявляється на прикладі окремих творчих одиниць та яким чином доречно виховувати цю якість для успішної профресійної діяльності.

Аналіз останніх досліджень і публікацій. Аспекти фрахового мислення музиканта-виконавця аналізує в науковій статті М. Давидов. Питання особливостей розуміння універсальності творчої особистості в українській музичній культурі ґрунтовно розкривається в дисертаційному дослідженні О. Коменди. Вплив системної діяльності на фрормування музичного мислення особистості 
окреслено в праці Г. Нагорної. Специсріка обробки музичного матеріалу та його підготовки до виконання описана у публікації Л. Остапенко. Ці наукові опрацювання стосуються різних аспектів виконавської діяльності музикантів, особливостей їх творчого зростання та навчального процесу.

Виділення не вирішених раніше частин загальної проблеми. Розвиток виконавської практики та оновлення методик здійснюється повсякчасно. За рахунок суб'єктивних та об'єктивних чинників збільшується можливість виконувати чимало фонкцій одним виконавцем, проте це питання не досить вивчене, а саме підґрунтя універсальності виконавця та шляхи її втілення.

Мета статті полягає у дослідженні універсальності як комплексу характеристик, що актуалізується в сучасному музичному виконавстві. Реалізація цієї мети також передбачає виділення основних підходів, які можуть застосовуватися для фрормування універсальності музикантів-виконавців.

Виклад основного матеріалу. Універсальність виконавця $є$ одним із понять, що почало привертати увагу науковців як самостійний предмет розвідок. Зокрема, О. Коменда у своєму дисертаційному дослідженні надає визначення універсальної особистості, яка діє в музичній культурі. Це - «творча особистість, для якої характерно поєднання не менше трьох видів діяльності, серед яких розрізняють провідні і допоміжні, конфрігурація яких на різних стадіях розвитку особистості, а також 3 погляду всього творчого шляху універсальної особистості й визначає ії̈ загальний профріль або тип» [2, с. 381].

Авторка зосереджує ракурс своїх розробок на цьому понятті, здійснюючи типологізацію митців, які мали провідний тип діяльності та поєднували його $з$ іншими формами активності, що мали важливе соціальне та культурне значення. Вона наголошує на існуванні «провідної діяльності, що в рамках концепції діяльнісного універсалізму трактується як діяльність, позначена масштабністю, тривалістю, цінністю для митця, його сучасників і нащадків, всередині якої зароджуються нові види діяльності» [2, с. 381]. Цей концепт є правильним у випадку більшості музичних діячів, творчі вияви яких розглядалися О. Комендою.

Варто наголосити, що існує відмінність між універсальністю виконавця та артистизмом. Мається на увазі, що будь-який виконавець у процесі гри чи співу повинен поєднувати їх із акторською грою, вмінням комунікувати 3 аудиторією. Ця синтетичність виконавської справи не може бути ототожнена 3 універсальністю. На думку М. Давидова, артистизм - це «два аспекти комунікативної поведінки виконавця на сцені - самовираження і свідоме психологічне взаємоспілкування музиканта зі слухацькою аудиторією: театральність і глибока змістовність музикування» [1, с. 95].
Назвати музичного діяча універсальною особистістю можна тоді, коли він виявляє себе одночасно як співак, інструменталіст, композитор, диригент, музичний критик. Цей рівень виконавської профресійної досконалості був доречним раніше і залишається актуальним нині. Якщо говорити про вміння добре грати на кількох музичних інструментах та водночас володіти мистецтвом співу творів, написаних чи аранжованих виконавцем, то це вже виходить за межі традиційного звичного артистизму, що $є$ широко розповсюдженим та обов'язковим, а тому претендує на те, щоб митці, які здійснюють полівекторну діяльність у сорері музичного мистецтва, могли називатися універсальними.

Внаслідок зменшення кількості культурно-мистецьких подій, а також введення карантинних заходів, яке спостерігається протягом 2020-2021 років, зростає необхідність фрормувати художнє ціле, залучаючи якомога менше виконавців. Такий підхід дозволяє не лише збільшити рентабельність мистецького продукту, а й знижує кількість контактувань 3 іншими учасниками музичного процесу (виконавці, звукорежисери), що багато в чому стає новою нормою сьогодення. До такої практики почало вдаватися чимало виконавців, облаштовуючи онлайн-виступи з власних осель, демонструючи репетиції чи інші етапи підготовки музичного продукту. Такі проєкти реалізовувалися і раніше, до пандемії, будучи альтернативою до концертної виконавської діяльності, що використовувалися для привернення додаткової уваги до виконавців. Проте сучасні умови підкреслили те, що часто лише онлайн-орорма виступів стає можливою. Саме в ній передаються необхідні навички роботи співака із звукопідсилювальною та звукозаписною технікою, гри на одному чи кількох (хоча б на кількох перкусійних) інструментах та одночасного співу.

Є музиканти, які почали розвивати різні сорери власної виконавської діяльності ще до того, як це стало суспільною потребою. Зокрема, доцільно розглянути творчість Джейкоба Кольєра (Jacob Collier). Цей досить молодий англійський виконавець у 23 роки вже отримав кілька Grammy, що $€$ вражаючим показником визнання досягнень у музичній діяльності. Проте ще більш важливим $\epsilon$ те, що його активність у музичній сорері наразі охоплює усі галузі: виконавство, як вокальне, так і інструментальне, композиторську справу, аранжування. Його здатність творчо переосмислювати твори сприяла значній популярності серед слухацької аудиторії. Його інтерпретація відомої пісні "Don't You Worry 'Bout A Thing” Стіві Уандера, яка увійшла до першого альбому "In My Room”, стала роботою, що заслуговує на увагу. Джейкоб Кольєр самостійно аранжував композицію. Було значно змінено не лише стиль пісні та виконавський 
склад, додано нові лінії фрактури, здійснено перегармонізацію, але й змінено структуру твору. Хоча базисною залишається куплетна фрорма, проте додається своєрідна фрорма другого плану (проста тричастинна зі вступом і кодою).

У стильовому відношенні в творі вибудовуються дві сорери. Перший розділ виконується а capella, причому фрактура розписана на шість голосів. У цьому епізоді превалює складна гармонія, що вирізняється від версії Стіві Уандера. Це джазові акорди із надбудовою (септакорди, нонакорди, ундецим акорди із затриманнями). Ритміка $€$ досить простою, спостерігається повільний темп і рух рівними тривалостями. Проте другий розділ твору постає у більш танцювальній образній сорері. Превалює домінування інструментального начала. У стильовому відношенні - це швидка самба. В цьому розділі поєднується гра різних музичних інструментів: гітара, контрабас, лютня, бонги, дарбука, кахон, бубон, клавес, музичний трикутник, ударна установка, синтезатор і спів. Причому наявні не лише вокально-інструментальні, а й суто інструментальні розділи.

Надзвичайно важливим є те, що усі вокальні та інструментальні партії виконані на високому профресійному рівні. Вокальна партія дозволила продемонструвати вокальну вправність, гарний гармонічний слух та інтонаційну точність. До того ж виконавець зміг самостійно записати усі треки та здійснити мастерінг. Тобто власноруч він зміг проробити великий масив завдань, які постають перед профресійними звукорежисерами при студійній роботі.

Л. Остапенко описує фрункціональні обов'язки звукорежисера. Він «попередньо з'ясовує, які технічні ефекти він повинен застосувати під час роботи над створенням фонограм: реверберація, використання голосового тюнінгу. Цей фрахівець зазвичай має музичну підготовку, оскільки йому доводиться записувати акомпанемент як відтворений на синтезаторах, так і ансамблем музикантів, отже, фрормувати звукові доріжки й акустичні коридори, а тому володіти ремеслом мікшування, еквалізації, зведення й мастерінгу» [4, с. 206]. Створений Джейкобом Кольєром запис, який до того ж містив відео, яке включало усі його виконавські амплуа, дозволяє переконатися у високій майстерності музиканта та його здатності бути не лише універсальним мультиінструменталістом, а й блискучим аранжувальником та звукорежисером.

У власному хіті "Sleeping On My Dreams" виконавець демонструє здатність створювати пісню та її аранжування не лише шляхом використання програмного забезпечення, але й завдяки грі на акустичних інструментах: контрабасі, фрортепіано, акустичній гітарі, ударних, перкусії. До того ж під час швидкої зміни інструментів Кольєр встигає застосовувати луп-машину, синтезатор і різні прилади для обробки голосу у реальному часі.

Кольєр може не лише співати у власній студії та записувати складні треки, які зрідка хто міг би виконати у реальному режимі наживо, а й здатний презентувати себе як концертний виконавець. У своїй подальшій діяльності він продемонстрував здатність не менш добре виступати на сцені, здійснивши у 2015 році тур по Європі та США, під час яких він використовував апаратуру та програмне забезпечення, створені для нього Беном Блумбергом.

Також серед здобутків Джейкоба $є$ концертні виступи із Metropole Orkest на джазовому фестивалі North Sea Jazz Festival у 2017 році, причому чимало композицій, зокрема "Hideaway", було аранжовано та оркестровано саме Кольєром. Це дозволяє високо оцінювати досягнення музиканта. У творчому доробку виконавця $€$ співпраця 3 іншими провідними американськими, британськими та канадськими музикантами. Так, масштабним проєктом, який зібрав учасників різних колективів, став запис композиції "All Night Long" Кольєром разом не лише з Metropole Orkest, а й із вокальним акапельним секстетом Take 6, який відноситься до зірок сцени.

Універсальність виконавця виявляється і у тому, що співак оволодів різними стилями та вокальними манерами. Вокальна манера характеризується використанням фральцету, легкого звучання, де превалює спів без опори. Його манера презентації музичних творів характеризується значною експресією, динамічністю зміни музичних інструментів та прийомів гри на них, відкритістю. Значна неординарність виконавця привертає симпатію публіки, яка бурхливо реагує на концертних виступах, перебуваючи в неменшому захваті, ніж Кольєр.

Його вокальні здібності насамперед розкриваються не завдяки розгорнутим соло для голосу, де, ймовірно, виконавець міг би поступитися у силі звуку, амплітуді чи якості артикуляції іншим співакам, які сконцентровані саме на цій сорері виконавства. Проте поєднання якостей інструменталіста, співака та творця музичного цілого роблять його зразковим виконавцем, гідним наслідування. Не останню роль у виконавській майстерності Кольєра відіграє розвинений музичний слух, завдяки якому виконавець не лише здатний гармонізувати мелодичну лінію будь-якої складності, але й зімпровізувати голосом майстерний контрапункт. Тобто, наявний зв'язок між різними навичками, які й фрормують результат, - музичний продукт, представлений музикантом.

«Основним критерієм істинності профресійного мислення майбутнього музиканта $€$ його діяльність, точніше ієрархія видів діяльності, де кожний наступний містить у собі попередній, 
де дослідницька самокритична діяльність педагога-музиканта як цілісна єдність об'єднує множину видів» [3, с. 47]. Це висловлювання можна екстраполювати таким чином: велику роль у формуванні універсальності виконавця відіграє високий рівень його теоретичної підготовки та досконале опанування такими дисциплінами, як «Сольфреджіо», «Гармонія», «Поліфонія», «Аранжування», «Інструментознавство». Нерідко музиканти-виконавці нехтують їх ґрунтовним вивченням, віддаючи пальму першості студентам спеціальностей «Теорія музики» та «Композиція».

Звісно, що універсальність виконавця виявляється не лише завдяки індивідуальним якостям, також необхідне потужне технічне забезпечення творчого процесу. Вітчизняна практика підготовки музикантів потребує коригування. Хоча існує чимало гарних викладачів як вокалістів, так і інструменталістів, які можуть розвивати певні окремі вміння та навички у студента, але поки мало хто здатний виховувати мультиінструменталіста-співака. Наріжною проблемою постає недостатнє технічне оснащення як студентів, так і педагогів. Адже кожен музичний інструмент, не кажучи вже про програмне забезпечення та технічне устаткування, $€$ досить вартісними. Тому на шляху до фрормування вітчизняних виконавців, які б володіли такими ж навичками, як Джейкоб Кольєр, необхідним етапом постає створення спеціалізованих творчих лабораторій, де був би потрібний набір інструментів та різних мануалів для реалізації творчого потенціалу виконавців. Важливим чинником $€$ і подолання психологічної неготовності студентів до опанування різних творчих іпостасей - від виконавської до звукорежисерської та композиторської. Це питання можна розвивати завдяки демонстрації зразків виконавської практики, показу можливостей застосування отриманих навичок у профресійній діяльності.
Висновки. Отже, універсальність музикантіввиконавців наразі $є$ досить важливою для сучасної музичної практики. Вона виступає мірилом адаптації до соціокультурних умов сьогодення та дозволяє переконатися у високому професійному рівні артиста. Джейкоб Кольєр є мультиінструменталістом-співаком, чий творчий шлях може слугувати зразком у питанні фрормування універсальності виконавської діяльності. Комплекс дій, які мають впроваджуватися для реалізації подібного рівня виконавства, включає забезпечення закладів освіти мистецького спрямування технічним обладнання, інструментарієм та кваліфікованими педагогічними кадрами. Також важливим компонентом є високий рівень вивчення музичнотеоретичних дисциплін, а не лише виконавської практики. Розвинений слух, гармонічне чуття допомагають удосконалювати рівень професіоналізму виконавця та виходити на більш високий рівень майстерності.

\section{БІБЛІОГРАФІЧНИЙ СПИСОК:}

1. Давидов М. Аспекти фрахового мислення музиканта-виконавця. Актуальні питання гуманітарних наук : міжвузівський збірник наукових праць молодих вчених Дрогобицького державного педагогічного університету імені Івана Франка, 2013. Вип. 7. С. 93-118.

2. Коменда О.І. Універсальна творча особистість в українській музичній культурі. Дис. докт. мистецтвознавства: 17.00.03 - музичне мистецтво; Національна музична академія України імені П.І. Чайковського. Київ, 2020. 519 с.

3. Нагорна Г.О. Дослідницька діяльність як фрактор фрормування музичного мислення особистості. Педагогічна освіта: теорія і практика. Психологія. Педагогіка, 2018. № 30. С. 46-52.

4. Остапенко Л. Засади фрормування пісенного репертуару. Матеріали щорічної науково-практичної інтернет-консреренції просресорсько-викладацького складу, докторантів, аспірантів, магістрів і студентів «Музика в діалозі з сучасністю: мистецькі, педагогічні, комунікаційні аспекти музичної культури України XXI століття». Київ : КНУКіМ, 2020. С. 204-206. 